\title{
KEABSAHAN PERATURAN DAERAH DALAM RANGKA PENYELENGGARAAN OTONOMI DAERAH
}

\author{
Akhmad Nikhrawi Hamdie \\ FISIP, Universitas Islam Kalimantan MAB (UNISKA) Banjarmasin \\ Email: nikhrawi2014@yahoo.com
}

\begin{abstract}
The existence of regional authority to make regional regulations for their own region based on the principle of regional autonomy does not mean that the regional government is sovereign, because supervision and supreme power still remain in the hands of the central government. According to Law Number 32 Year 2004 regarding Regional Government there are two signs that should not be violated by regional regulations, namely: (a) contrary to public interest, and / or (b) contrary to higher laws and regulations. Regarding the criterion is against the public interest, Law Number 32 Year 2004 does not regulate it clearly and specifically. However, Article 4 Paragraph (4) of Kepmendagri Number 41 Year 2001 concerning Technique of Represive Control of Regional Policies which is actually a regulation of the implementation of Law Number 22 Year 1999, declared the general interest as meant in Article 4 paragraph (3) letter a, Or customs prevailing in an area, such as religious norms, customs, culture, and morals, as well as things that burden the public and incur high economic costs. Meanwhile, the higher laws and regulations as referred to in Article 4 paragraph (3) b, covering the 1945 Constitution, MPR Decrees, Laws, Government Regulations, Presidential Decrees, and Ministerial Decrees.
\end{abstract}

Keywords: regional regulation, regional autonomy, public interest

\section{PENDAHULUAN}

Perda dibentuk berdasarkan atau atas perintah dari peraturan yang lebih tinggi, yaitu UUD 1945 dan undang-undang. Perintah dari peraturan yang tingkatannya lebih tinggi untuk membentuk peraturan yang tingkatannya lebih rendah itu oleh Soehino (2000:160) disebut delegasi perundang-undangan. Delegasi perundang-undangan yang memberikan wewenang kepada pemerintahan daerah untuk membentuk Perda merupakan wujud penerapan prinsip dan kebijakan desentralisasi.

Terkait dengan kewenangan pemerintahan daerah membuat Perda untuk mengatur dan mengurus pemerintahannya sendiri berdasarkan prinsip otonomi yang luas, nyata dan

\section{Rumusan Masalah}

Masalah pokok yang diteliti dan dianalisis dalam penelitian ini adalah Bagaimana tolok ukur pengujian terhadap keabsahan peraturan daerah (Perda) serta upaya hukum apa yang bertanggungjawab, persoalan yang muncul adalah apakah cita hukum (rechtsidee) yang diharapkan oleh pembuat undang-undang dengan kebijakan desentralisasi itu telah berjalan sesuai dengan koridor hukum yang berlaku? Karena kenyataanya, menurut pengamatan Safri Nugraha (2004:27) saat ini ada ribuan Perda di tingkat provinsi, kabupaten dan kota telah dibatalkan pemerintah pusat karena berbagai alasan, di antaranya Perda-perda tersebut membebani investor, materinya mengatur urusan yang bukan kewenangan atau melampaui kewenangan yang diberikan, dan sebagainya. Masalah tersebut menjadi semakin kompleks ketika pemerintahan daerah menolak pembatalan Perda mereka dan menuduh pemerintah pusat telah melakukan upaya resentralisasi kekuasaan. dapat dilakukan oleh pemerintah daerah dalam mengajukan keberatan atas pembatalan peraturan daerah yang dilakukan oleh pemerintah (pusat)? 


\section{PEMBAHASAN}

Berdasarkan pasal 70, 113 dan 114 Undang-undang Nomor 22 Tahun 1999 terdapat tiga elemen utama yang menjadi rambu-rambu larangan materi muatan peraturan daerah, ketiga rambu tersebut adalah: (a) bertentangan dengan kepentingan umum; (b) bertentangan dengan peraturan daerah lain; dan (c) bertentangan dengan peraturan perundang-undangan yang lebih tinggi. Sedangkan menurut pasal 145 ayat (2) dan 146 ayat (2) Undang-undang Nomor 32 Tahun 2004 tentang Pemerintahan Daerah yang mencabut berlakunya Undang-undang Nomor 22 Tahun 1999 ada dua rambu-rambu yang tidak boleh dilanggar oleh peraturan daerah, yaitu: (a) bertentangan dengan kepentingan umum, dan/atau (b) bertentangan dengan peraturan perundang-undangan yang lebih tinggi.

\section{a. Bertentangan Dengan Kepentingan Umum}

Persoalan akademis dan yuridis yang mengedepan ialah apa tolok ukur bertentangan dengan kepentingan umum? Ternyata Undangundang Nomor 22 Tahun 1999 dan Undangundang Nomor 32 Tahun 2004 tidak mengaturnya secara jelas dan spesifik. Demikian pula menurut Kepmendagri Nomor 41 Tahun 2001 tentang Teknik Pengawasan Represif Kebijakan Daerah. Pasal 4 ayat (3) menentukan pembatalan peraturan daerah dilakukan apabila bertentangan dengan: a. kepentingan umum; $b$. peraturan perundang-undangan yang lebih tinggi; dan c. peraturan perundang-undangan yang lainnya. Hal ini dipertegaskan dalam pasal 5:

(1) kepentingan umum sebagaimana dimaksud dalam pasal 4 ayat (3) huruf a, meliputi kepatutan atau kebiasaan yang berlaku di suatu daerah, seperti norma agama, adat istiadat, budaya, dan susila, serta hal-hal yang membebani masyarakat dan menimbulkan biaya ekonomi tinggi;

(2) peraturan perundang-undangan yang lebih tinggi sebagaimana dimaksud dalam pasal 4 ayat (3) huruf b, meliputi UUD 1945, Ketetapan MPR, Undang-undang, Peraturan Pemerintah, Keputusan Presiden (baca: Peraturan Presiden), dan Keputusan Menteri (baca: Peraturan Menteri);
(3) peraturan perundang-undangan yang lainnya sebagaimana dimaksud dalam pasal 4 ayat (3) huruf c, meliputi peraturan daerah propinsi dan/atau peraturan gubernur serta peraturan daerah kabupaten atau kota dan/atau peraturan bupati atau walikota yang mengatur obyek sejenis.

Menurut Bagir Manan (2002:140), Perda yang bertentangan dengan kepentingan umum, belum pernah ada kesepakatan hukum atau ilmiah mengenai pengertian dan lingkup kepentingan umum. Sungguhpun demikian, Bagir Manan telah menentukan beberapa ukuran yang dapat dipergunakan untuk menentukan kepentingan umum, yaitu: pertama, dibutuhkan orang banyak. Kedua, setiap orang dapat menikmati dan memperoleh manfaat tanpa ada pembatasan karena kondisi individual seseorang; Ketiga, harus dalam rangka kesejahteraan umum baik dalam arti materiil maupun spiritual. Selain itu, Bagir Manan juga menjelaskan bahwa di Belanda sebelum perubahan UUD (Grondwet) 1983 pengertian "bertentangan dengan kepentingan umum" dikembangkan dalam yurisprudensi, termasuk bertentangan dengan peraturan perundang-undangan di luar undangundang (wet). Tetapi setelah perubahan UUD 1983, istilah "bertentangan dengan undangundang" diganti dengan rumusan yang lebih luas ialah "bertentangan dengan hukum".

Lebih lanjut dijelaskan oleh Bagir Manan, jika pendekatan di Belanda diterapkan di Indonesia, maka substansi makro bertentangan dengan kepentingan umum dalam sistem pengawasan represif dapat meliputi:

1) bertentangan dengan prinsip-prinsip umum yang terkandung dalam Pembukaan UUD 1945 (di luar dasar negara);

2) bertentangan dengan Pancasila sebagai dasar negara;

3) bertentangan dengan asas-asas hukum yang berlaku;

4) bertentangan dengan asas-asas hukum umum pemerintahan yang layak;

5) bertentangan dengan kebijksanaan umum peraturan yang lebih atas tingkatannya;

6) bertentangan dengan keputusan-keputusan pemerintah yang lebih atas yang tidak tergolong sebagai peraturan perundangundangan; 
7) bertentangan dengan kepentingan dan menimbulkan kerugian pada daerah lain.

Sebaliknya bertentangan dengan hukum adalah: (a) bertentangan dengan semua peraturan perundang-undangan yang lebih tinggi tingkatannya, (b) bertentangan dengan hukum adat yang hidup dan diakui, (c) bertentangan dengan kaidah-kaidah hukum yang lahir dari yurisprudensi, (d) bertentangan dengan kaidahkaidah kebiasaan ketatanegaraan yang berlaku umum.

Terdapat pendapat Bagir Manan yang memasukkan alasan "bertentangan dengan asasasas hukum umum pemerintahan yang layak", menurut Wiyono (2004:34) hal itu hanya relevan jika diterapkan pada pembuatan beschikking, yakni Keputusan Tata Usaha Negara (KTUN) yang bersifat konkrit, individual, dan final. Sementara itu, untuk pembentukan peraturan daerah sangat relevan jika dipakai pandangan I Gde Pantja Astawa, yang merumuskan tolok ukur kepentingan umum dengan indikator:

1) kepentingan daerah yang bersangkutan/setempat, ialah sejauh mana partisipasi masyarakat dilibatkan ke dalam proses pembentukan peraturan daerah;

2) kepentingan daerah lain dan kepentingan nasional, berdasarkan otonomi daerah menurut Undang-undang 32 Tahun 2004, bahwa pelaksanaan otonomi harus sesuai dengan konstitusi negara, sehingga tetap terjamin hubungan yang serasi antara pusat dan daerah serta antar daerah;

Istilah kepentingan umum juga dinormatifkan dalam pasal 1 Undang-undang Nomor 20 Tahun 1961 tentang Pencabutan Hakhak atas Tanah dan Benda-benda di atasnya. Bahwa untuk "kepentingan bangsa dan negara serta kepentingan bersama rakyat dan kepentingan pembangunan", Presiden dalam keadaan memaksa setelah mendengar Menteri Agraria (sekarang Kepala Badan Pertanahan Nasional), Menteri Kehakiman dan Menteri yang bersangkutan, dapat mencabut hak-hak atas tanah dan benda-benda yang ada di atasnya. Hal tersebut kemudian dijelaskan dan diperluas cakupannya dengan Instruksi Presiden Nomor 9 Tahun 1973 yang menentukan kriteria pelaksanaan pembangunan bersifat "kepentingan umum" meliputi: (1) kepentingan bangsa dan negara dan/atau, (2) kepentingan masyarakat luas dan/atau, (3) kepentingan rakyat banyak/bersama dan/atau, (4) kepentingan pembangunan, terdiri atas: (a) pertahanan; (b) pekerjaan umum; (c) perlengkapan umum; (d) jasa umum; (e) keagamaan; (f) ilmu pengetahuan dan seni budaya; (g) kesehatan; (h) olah raga; (i) keselamatan umum terhadap bencana alam; (j) kesejahteraan sosial; (k) makam/kuburan; (l) pariwisata dan rekreasi; (m) usaha-usaha ekonomi yang bermanfaat bagi kesejahteraan umum.

Menurut Wiyono (2004:35), dalam konteks pengawasan represif terhadap pembatalan peraturan daerah perlu dirumuskan tolok ukur bertentangan dengan "kepentingan umum" agar diperoleh kepastian hukum secara optimal. Selain itu, hal itu juga menjadi ramburambu bagi pemerintah daerah dalam membentuk dan memberlakukan peraturan daerah. tolok ukur kepentingan yang diformulasikan oleh Bagir Manan dan I Gde Pantja Astawa di atas dapat dijadikan patokan umum, namun konkritisasinya perlu diperjelas dengan kriteria sebagaimana disajikan pada tabel berikut ini. 
Tabel 1. Kriteria Kepentingan Umum

\begin{tabular}{|c|c|c|}
\hline No. & Unsur & Kriteria \\
\hline 1 & $\begin{array}{l}\text { Bertentangan dengan prinsip- } \\
\text { prinsip yang terkandung } \\
\text { dalam Pembukaan UUD } 1945 \\
\text { (di luar dasar negara) }\end{array}$ & $\begin{array}{l}\text { Apabila dasar pertimbangan, konsiderans mengingat, } \\
\text { tujuan dan materi muatan Perda nyata-nyata } \\
\text { bertentangan dengan: } \\
\text { 1. prinsip negara melindungi segenap bangsa dan } \\
\text { seluruh tumpah darah Indonesia dari segala bentuk } \\
\text { ancaman yang datangnya dari luar maupun dari } \\
\text { dalam negeri terhadap desintegrasi NKRI; } \\
\text { 2. prinsip negara memajukan kesejahteraan umum } \\
\text { (segenap rakyat Indonesia) khususnya rakyat di } \\
\text { daerah bersangkutan; } \\
\text { 3. prinsip negara memajukan dan mencerdaskan } \\
\text { kehidupan bangsa khususnya rakyat di daerah } \\
\text { bersangkutan; } \\
\text { 4. prinsip negara memajukan perdamaian abadi dalam } \\
\text { pergaulan masyarakat internasional, khususnya } \\
\text { antara daerah yang bersangkutan yang berbatasan } \\
\text { dengan negara tetangga; } \\
\text { 5. prinsip negara mewujudkan kesejahteraan sosial } \\
\text { bagi segenap rakyat Indonesia, khususnya } \\
\text { kesejahteraan rakyat di daerah bersangkutan; }\end{array}$ \\
\hline 2 & $\begin{array}{l}\text { Bertentangan dengan } \\
\text { Pancasila sebagai dasar negara }\end{array}$ & $\begin{array}{l}\text { Apabila: dasar pertimbangan, konsiderans mengingat, } \\
\text { tujuan, dan materi muatan Perda nyata-nyata } \\
\text { bertentangan dengan kelima sila Pancasila }\end{array}$ \\
\hline 3 & $\begin{array}{l}\text { Bertentangan dengan asas-asas } \\
\text { hukum yang berlaku }\end{array}$ & $\begin{array}{l}\text { Apabila: dasar pertimbangan, konsiderans mengingat, } \\
\text { tujuan, dan materi muatan Perda nyata-nyata } \\
\text { bertentangan prinsip persamaan di depan hukum dan } \\
\text { HAM, khususnya hak rakyat di daerah bersangkutan di } \\
\text { bidang kehidupan politik, ekonomi, sosial, budaya, dan } \\
\text { hankam }\end{array}$ \\
\hline 4 & $\begin{array}{l}\text { Bertentangan dengan asas-asas } \\
\text { hukum umum pemerintahan } \\
\text { yang layak }\end{array}$ & $\begin{array}{l}\text { Ini hanya relevan bagi pembentukan keputusan kepala } \\
\text { daerah yang bersifat konkrit, individual dan final. } \\
\text { Apabila: dasar pertimbangan, konsiderans mengingat, } \\
\text { tujuan, dan materi muatan keputusan kepala daerah } \\
\text { yang bersifat penetapan untuk melaksanakan Perda } \\
\text { dan/atau peraturan perundang-undangan lainnya, } \\
\text { ternyata bertentangan dengan asas: (a) kepastian } \\
\text { hukum, (b) keseimbangan, (c) kesamaan pengambilan } \\
\text { keputusan, bertindak cermat, (d) motivasi, penerapan } \\
\text { aturan yang benar, (e) larangan bertindak sewenang- } \\
\text { wenang, pemenuhan pengharapan yang layak }\end{array}$ \\
\hline 5 & $\begin{array}{l}\text { Bertentangan dengan } \\
\text { kebijaksanaan umum } \\
\text { peraturan yang lebih atas } \\
\text { tingkatannya }\end{array}$ & $\begin{array}{l}\text { Apabila: dasar pertimbangan, konsiderans mengingat, } \\
\text { tujuan, dan materi muatan Perda nyata-nyata } \\
\text { bertentangan dengan materi muatan yang seharusnya } \\
\text { diatur oleh peraturan perundang-undangan yang lebih } \\
\text { tinggi tingkatannya }\end{array}$ \\
\hline
\end{tabular}




\begin{tabular}{|c|c|c|}
\hline 6 & $\begin{array}{l}\text { Bertentangan dengan } \\
\text { keputusan pemerintah lebih } \\
\text { atas yang tidak tergolong } \\
\text { sebagai peraturan perundang- } \\
\text { undangan }\end{array}$ & $\begin{array}{l}\text { Apabila: dasar pertimbangan, konsiderans mengingat, } \\
\text { tujuan, dan materi muatan Perda nyata-nyata } \\
\text { bertentangan dengan instruksi atau surat edaran yang } \\
\text { dikeluarkan oleh badan atau pejabat pemerintahan } \\
\text { yang lebih tinggi tingkatannya. Namun dalam praktik } \\
\text { penyelenggaraan pemerintahan dinilai sebagai } \\
\text { pedoman yuridis yang berlaku sah dan bersifat umum }\end{array}$ \\
\hline 7 & $\begin{array}{l}\text { Bertentangan dengan } \\
\text { kepentingan daerah } \\
\text { bersangkutan/setempat }\end{array}$ & $\begin{array}{l}\text { Jika pembentukan Perda kurang/tidak melibatkan } \\
\text { partisipasi (aspirasi) masyarakat setempat yang } \\
\text { berkepentingan langsung maupun tidak langsung } \\
\text { dengan eksistensi Perda yang dibentuk }\end{array}$ \\
\hline 8 & $\begin{array}{l}\text { Bertentangan dengan } \\
\text { kepentingan dan menimbulkan } \\
\text { kerugian pada daerah lain }\end{array}$ & $\begin{array}{l}\text { Apabila: dasar pertimbangan, konsiderans mengingat, } \\
\text { tujuan, dan materi muatan Perda nyata-nyata } \\
\text { bertentangan dengan kepentingan dan/atau } \\
\text { menimbulkan kerugian pada daerah otonom lainnya: } \\
\text { propinsi, kabupaten, kota, maupun desa. }\end{array}$ \\
\hline 9 & $\begin{array}{l}\text { Bertentangan dengan } \\
\text { kepentingan nasional }\end{array}$ & $\begin{array}{l}\text { Apabila: dasar pertimbangan, konsiderans mengingat, } \\
\text { tujuan, dan materi muatan Perda nyata-nyata } \\
\text { bertentangan dengan konstitusi dan peraturan } \\
\text { perundang-undangan tingkat pusat yang menyebabkan } \\
\text { terganggu, terhambat, dan terancamnya harmonisasi } \\
\text { hubungan pusat dan daerah. }\end{array}$ \\
\hline
\end{tabular}

Sumber: Wiyono, 2004:35-37

\section{b. Bertentangan Dengan Peraturan Daerah Lain}

Elemen ini berkaitan dengan uraian pada butir 8 tabel di atas. Tanpa menutup kemungkinan peraturan daerah yang dibuat oleh pemerintah propinsi, kabupaten dan kota dapat bertentangan atau merugikan daerah lainnya yang bertetangga (berbatasan langsung), apalagi dengan adanya pemebentukan atau pemekaran daerah otonom baru. Semula pengaturan urusan otonomi diatur sepenuhnya oleh suatu daerah yang belum dimekarkan, namun setelah dimekarkan dapat terjadi konflik pengaturan (kepentingan) dengan daerah otonom baru.

Pengaturan rencana tata ruang wilayah daratan dari 4 mil laut dalam rangka penataan ruang bagi kawasan lindung, kawasan budi daya, kawasan pesisir, kawasan pedesaan dan sumber daya alam yang terkandung di dalamnya berpeluang menciptakan konflik kepentingan antara daerah propinsi, kabupaten, kota dan desa.

\section{c. Bertentangan Dengan Peraturan \\ Perundang-Undangan Yang Lebih Tinggi}

Terhadap tolok ukur bertentangan dengan peraturan perundang-undangan yang lebih tinggi tingkatannya, Wiyono (2004:37) berpendapat seyogyanya memang perlu diperluas menjadi "bertentangan dengan hukum". Sebab, jika hanya dibatasi pada peraturan perundang-undangan tertulis, maka jika peraturan daerah bertentangan dengan hukum adat yang diakui eksistensinya ataupun konvensi ketatanegaraan, maka peraturan daerah tersebut menjadi tidak dapat dibatalkan.

Persoalannya bagaimanakah menentukan suatu peraturan daerah "bertentangan dengan hukum"? Kriterianya dapat ditentukan antara lain sebagai berikut:

(1) Mencermati dengan seksama asas-asas penyusunan peraturan daerah sebagaimana dikemukakan oleh I Dewa Gede Atmadja, sangat layak dipedomani yaitu:

a. wewenang untuk membuat, baik berdasarkan konstitusi, delegasi, tugas pembantuan maupun atas inisiatif daerah sesuai prinsip otonomi nyata dan bertanggung jawab, kemampuan dan kesanggupannya;

b. prosedur penyusunan dan pengesahan bentuk peraturan;

c. sistematika peraturan tersebut. 
(2) Syarat prosedural, yang meliputi mekanisme pembentukan peraturan daerah yang diperintahkan peraturan perundangundangan yang berlaku khusus untuk itu (Peraturan Tata Tertib DPRD), melalui tahapan:

a. usulan hak inisiatif baik oleh DPRD maupun Kepala Daerah;

b. Rapat Fraksi, Sidang Pleno, Rapat Paripurna, Pandangan Umum, Persetujuan, dan

c. Pengundangannya ke dalam Lembaran Daerah. Syarat ini tidak boleh cacat hukum, baik karena pengabaian salah satu prosedur yang wajib dilaksanakan maupun karena politik uang (money politic) misalnya;

d. Syarat formal, yang mengharuskan format peraturan peraturan daerah benar-benar bersesuaian dengan pedoman yang mengaturnya dan/atau kelaziman yang berlaku dalam penyelenggaraan pemerintahan daerah. termasuk keterkaitannya dengan asasasas pembentukan peraturan perundangundangan yang meliputi: (1) tujuan yang jelas; (2) organ/lembaga yang tepat; (3) kesesuaian antara jenis dan materi muatan; (4) dapatnya dilaksanakan; (5) kedayagunaan dan kehasilgunaan; (6) kejelasan rumusan; dan (7) keterbukaan (pasal 137 Undang-undang Nomor 32 Tahun 2004);

e. Syarat material, yang mengharuskan bahwa materi muatan peraturan daerah hanya dapat dibenarkan mengatur urusan otonomi (desentralisasi) ataupun tugas pembantuan (medebewind) yang secara konkrit maupun umum diatribusikan oleh undang-undang dan/atau didelegasikan oleh peraturan perundang-undangan lainnya yang berlaku:

(1) menyangkut urusan otonomi (desentralisasi) tolok ukur makronya seperti ditentukan dalam pasal 10, 13, dan 14 Undang-undang Nomor 32 Tahun 2004 ;

(2) untuk tolok ukur mikronya diatur oleh peraturan pelaksanaannya dalam bentuk delegasi (penyerahan) kewenangan ataupun pengakuan pelaksanaan kewenangan dan urusan oleh pemerintah pusat;

(3) menyangkut tugas pembantuan (medebewind) harus disesuaikan dengan peraturan perundang-undangan yang mengaturnya;

(4) peraturan daerah harus pula memiliki: a) terminologi dan sistematika yang benar; b) dapat dikenali; c) perlakuan yang sama dalam hukum; d) kepastian hukum; e) pelaksanaan hukum sesuai keadaan individual (Attamimi, 1990:340);

(5) peraturan daerah harus memenuhi syarat hirarki norma, artinya bahwa materi muatan peraturan daerah tidak boleh mengatur materi muatan yang seharusnya diatur oleh peraturan perundang-undangan yang lebih tinggi atau sederajat dan/atau yang materi muatannya sudah diatur oleh peraturan perundang-undangan lainnya, kecuali secara khusus (lex specialis) peraturan daerah memang dibenarkan mengaturnya;

(6) peraturan daerah secara konseptual juga harus memenuhi persyaratan validitas norma hukum, termasuk tentang arena pilihan bagi lembaga pembuat undangundang (Wiyono, 2004:38).

Menyangkut pengawasan represif terhadap Peraturan Daerah (termasuk di dalamnya Keputusan Kepala Daerah (baca: Peraturan Kepala Daerah), Peraturan DPRD, dan Peraturan Pimpinan DPRD, pasal 8 sampai dengan pasal 10 Peraturan Pemerintah Nomor 20 Tahun 2001 mengaturnya sebagai berikut:

a. pengawasan represif terhadap peraturan daerah dilakukan oleh Menteri Dalam Negeri setelah berkoordinasi dengan departemen/lembaga pemerintah non departemen;

b. pengawasan tersebut dapat dilimpahkan kepada gubernur selaku wakil pemerintah terhadap peraturan daerah, keputusan kepala daerah, keputusan DPRD, dan keputusan pimpinan DPRD kabupaten dan kota setelah berkoordinasi dengan instansi terkait;

c. keputusan pembatalan diterbitkan oleh Menteri Dalam Negeri atas nama Presiden terhadap peraturan daerah dan/atau keputusan kepala daerah propinsi, kabupaten dan kota; keputusan DPRD dan keputusan pimpinan DPRD propinsi, kabupaten dan kota yang bertentangan 
dengan kepentingan umum atau peraturan perundang-undangan yang lebih tinggi dan/atau peraturan perundang-undangan lainnya;

d. gubernur selaku wakil pemerintah menerbitkan keputusan pembatalan peraturan daerah, keputusan kepala daerah, keputusan DPRD, dan keputusan pimpinan DPRD kabupaten dan kota sesuai kewenangan yang dilimpahkan kepadanya;

e. daerah propinsi, kabupaten dan kota yang tidak dapat menerima keputusan pembatalan dimaksud oleh pemerintah dapat mengajukan keberatan kepada pemerintah melalui Menteri Dalam Negeri; dan

b. daerah kabupaten dan kota yang tidak dapat menerima keputusan pembatalan dimaksud oleh gubernur sesuai kewenangan yang dilimpahkan kepadanya dapat mengajukan keberatan kepada gubernur selaku wakil pemerintah di daerah.

\section{KESIMPULAN}

Adanya kewenangan daerah untuk membuat peraturan daerah bagi daerahnya sendiri berdasarkan prinsip otonomi daerah tidaklah berarti bahwa pemerintah daerah berdaulat, sebab pengawasan dan kekuasaan tertinggi masih tetap terletak di tangan pemerintah pusat. Oleh karena itu, dalam pembentukan peraturan daerah perlu memperhatikan asas-asas dalam pembentukannya serta batas-batas materi muatan yang boleh diatur dalam suatu peraturan daerah. Materi muatan Perda, menurut Pasal 12 Undangundang Nomor 10 Tahun 2004, meliputi: (1) seluruh materi muatan dalam rangka penyelenggaraan otonomi daerah dan tugas pembantuan; (2) materi muatan yang mengatur kondisi khusus daerah atau daerah otonom; dan (3) materi muatan yang merupakan penjabaran lebih lanjut atau delegasi wewenang dari peraturan perundang-undangan yang lebih tinggi.

\section{REFERENSI}

Attamimi, A. Hamid, 1990. Peranan Keputusan Presiden Republik Indonesia dalam Penyelenggaraan Pemerintahan Negara. Disertasi, Fakultas Pascasarjana Universitas Indonesia, Jakarta.

Bagir Manan, 1992. Dasar-dasar Perundangundangan Indonesia, Ind. Hill, Jakarta.

1994, Hubungan Antara Pusat dan daerah Menurut UUD 1945. Pustaka Sinar Harapan, Jakarta.

------------, 2002. Menyongsong Fajar Otonomi. PSH Fakultas Hukum UII, Yogyakarta

Bagir Manan dan Kuntana Magnar, 1997, Beberapa Masalah Hukum Tata Negara Indonesia, Alumni, Bandung.

Mochtar Kusumaatmadja, 1995. Pemantapan Cita Hukum dan Asas-asas Hukum Nasional di Masa Kini dan Masa yang Akan Datang, Makalah, Jakarta.

Oemar Seno Adji, 1980. Peradilan Bebas Negara Hukum. Erlangga, Jakarta.

Oentarto Sindung Mawardi, 2004, Permasalahan Implementasi Undang-undang Nomor 22 Tahun 1999, dalam Jurnal Hukum Bisnis, Vol. 23 No. 1 Tahun 2004.

Padmo Wahjono, 1983. Indonesia Negara Berdasarkan atas Hukum. Ghalia Indonesia, Jakarta.

Ronny Hanitijo Soemitro, 1990. Metodologi Penelitian Hukum dan Jurimetri. Ghalia Indonesia, Jakarta.

Rozali Abdullah, 2000. Pelaksanaan Otonomi Luas dan Isu Federalisme Sebagai Suatu Alternatif. Rajawali Press, Jakarta

Safri Nugraha, 2004. Problematik dalam Pengujian dan Pembatalan Perda oleh 
Pemerintah Pusat, dalam Jurnal Hukum Bisnis, Vol. 23 No. 1 Tahun 2004.

Seidman, Ann, et al., 2001. Penyusunan Rancangan Undang-undang dalam Perubahan Masyarakat yang Demokratis. Elieps, Jakarta. 